\title{
WESTERNIZATION OF THE OTTOMAN EMPIRE, ZIONISM AND THE RESISTANCE OF THE PALESTINIAN SOCIETY
}

\author{
Meirison \\ Fakultas Ekonomi dan Bisnis Islam UIN Imam Bonjol, \\ Padang, Sumatera Barat \\ e-mail : meirison@unib.ac.id
}

\begin{abstract}
Westernization due to backwardness in science and technology that was not taken care, because of their feeling of superiority over Europe. After underdevelopment in all areas, the Ottomans began reforms. However, the renewal focused on constitutions and parliaments that mimic the West, which fostered nationalism throughout the region. This facilitated Western intervention in the policies of the Ottoman government, which was very fragile and heavily in debt. Coupled with the defeat of the war with Russia and Western Europe. By conducting a historical discussion, the writer does a literature study and performs a comparative analysis of information and current events and develops them into a conclusion from the historical analysis obtained from various pieces of literature. Westernization is a gap opened by the West to change the Ottoman system of government in which Sultan Abdul Hamid II dissolved parliament. Westernization government after Sultan Abdul Hamid II had given support to Jews who favor Ottoman and Germans, but Jews only saw the opportunity to establish a Palestinian state with British support because basically, Ottoman Turkey which was motivated by Islamic Shari'at would be difficult to escape from the pressure of society Muslims and Arabs for the establishment of a Jewish state in Palestine. The Zionists had no choice but to support Britain

الملخص: التغريب الذي أجراه ا العثمانيون بسبب التخلف في العلوم والتكنولوجيا التي لم يتم الاعتناء بها بسبب شعورهم بتفوق على أوروبا. وبعد التخلف في جميع المجالات، بدأ
\end{abstract}


العثمانيون إجراء إصلاحات. ومع ذلك، ركز التجديد على الدساتير والبرلانات التي تحاكي

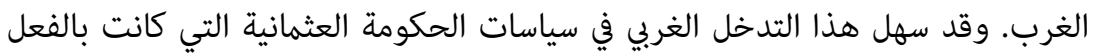

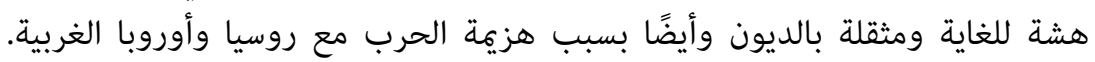

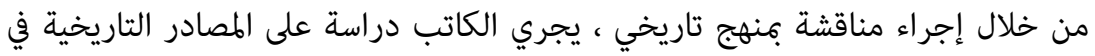

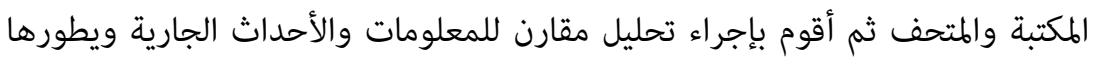

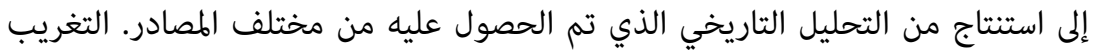

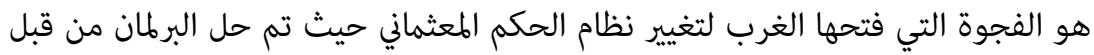

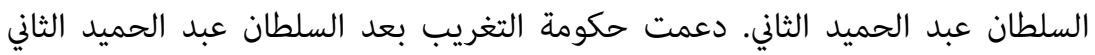

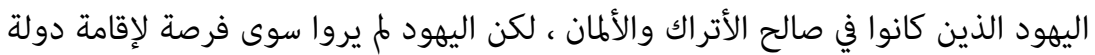

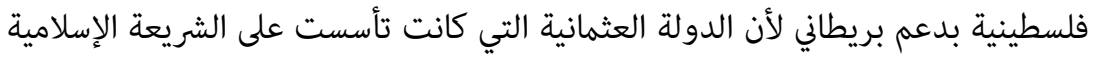

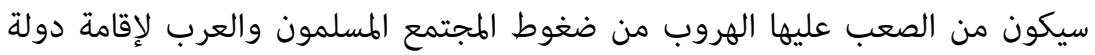
يهودية في فلسطين. مل يكن أمام الصهاينة خيار سوى دعم برويط فيطانيا

Abstrak: Westernisasi dilakukan akibat keterbelakangan ilmu pengetahuan dan teknologi yang selama ini tidak dipedulikan akibat supremasi Turki Usmani di Eropa. Setelah ketinggalan dalam segala bidang, Turki Usmani mulai melakukan pembaharuan. Akan tetapi, pembaharuan tersebut terfokus pada konstitusi dan parlemen dengan meniru Barat sehingga menumbuhkan nasionalisme di seluruh wilayah. Hal ini memudahkan campur tangan Barat terhadap kebijakan pemerintahan Turki Usmani yang telah sangat rapuh dan dililit hutang serta akibat kekalahan perang melawan Rusia dan Eropa Barat. Dengan pendekatan historis, penulis melakukan studi pustaka dan analisa komparatif terhadap informasi dan kejadian yang ada sekarang dan mengembangkannya menjadi sebuah kesimpulan dari analisa sejarah yang didapatkan dari berbagai literatur. Westernisasi merupakan celah yang dikuakkan oleh Barat untuk mengubah sistem pemerintahan Turki Usmani yang mana parlemen sempat dibubarkan oleh Sultan Abdul Hamid II. Pemerintahan westernisasi pasca sultan Abdul Hamid II sempat memberikan dukungan kepada Yahudi yang berpihak kepada Turki Usmani dan Jerman, akan tetapi Yahudi hanya melihat peluang mendirikan negara Palestina dengan dukungan Inggris karena pada dasarnya Turki Usmani yang dilatarbelakangi oleh 
Syariat Islam akan sulit melepaskan dari tekanan masyarakat Muslim dan Arab atas pendirian negara Yahudi di Palestina. Zionis tidak punya pilihan lain kecuali mendukung Inggris.

Keywords: Ottoman, palestinian society, resistance, westernization.

\section{INTRODUCTION}

Westernization is a renewal in various fields carried out by the Ottoman Empire, which adopted the Western-style in all respects. This had previously made improvements and updates during the family of Köprülü Fazıl Ahmed Pasa (1656-1703). ${ }^{1}$ A renewal that runs in the Ottoman style in accordance with what is needed by the Ottoman Empire in times of crisis that never fixed the joints of government such as law and governance structure. The Köprülü family comes from Albania, who had an adequate background in Islamic knowledge. ${ }^{2}$ The educated were close to the Sultans who mastered Turkish, Arabic, and Persian wherever they came from as Agha Samsuddin has been an advisor to Sultan Muhammad alFatih, in various ways. Agha Samsuddin mastered various disciplines outside fiqh and Sufism, such as biology, microbiology, falaq science, psychology to epidemiology. Not only that, the Imam also mastered mathematics, physics, and even political science. However, the situation led Ottoman Turks to degrade in many ways, one of which is the leadership crisis where the Ottoman Turks no longer have visionary leaders. Western-style lifestyles make needs increase even more with the longstanding leadership crisis. Westernization has been rife since 1838, which has cost a lot because Janissary also opposed it. European interference began to be seen clearly on the grounds of debt and westernization, which is itself reduced the sultan's power in government politics. Parliament is controlled by groups that support westernization in everything, especially in lifestyle. As Sultan Abdul

1 Yasir Y1lmaz, “Grand Vizieral Authority Revisited: Köprülüs’ Legacy and Kara Mustafa Pa'a," Mediterranean Historical Review 31, no. 1 (January 2, 2016): 21-42, doi:10.1080/09518967.2016.1173359.

2 Michael Ursinus, "From Süleyman Pasha to Mehmet Fuat Köprülü: Roman and Byzantine History in Late Ottoman Historiography," Byzantine and Modern Greek Studies 12, no. 1 (January 1988): 305-14, doi:10.1179/byz.1988.12.1.305. 
Majid (2 July 1839 - 25 June 1861) appealed to leave the Ottoman culture, which is thick with Islamic culture towards Western culture. So westernization permeates all lines of life, and French is the main language for scholars. The aim of the West in the westernization of the Ottoman Empire was to create a spirit of nationalism that would make the Ottoman territory divided into smaller territories and more comfortable to control and divide. In 1902 a conference was held, which was attended by 50 opposition Ottoman intellectuals, who tried to embrace the military to change the ideology of the Ottoman Empire. This Westernization, which was attempted by Ottoman scholars, was funded and supported by the Freemasonry group, which was a member of the Ottoman Parliament which was forced by the West due to westernization. Its representative was Emanuel Carraso, who carried out many riots and rebellions against Sultan Abdul Hamdi II. He collaborated with Italy so that he could easily colonize Libya, which at that time was an Ottoman province.

The position of the Ottoman was then replaced by Jews who settled in Palestine because the enormous wealth in the Middle East was higher than the cotton industry. The British entered into a Belfour agreement to get Jewish support in The First World War. The establishment of the Jewish state serves to safeguard the benefit of Britain in Egypt in guarding the Suez Canal, the road to India and the Far East, as well as blocking the ambitions of France to control Syria, Lebanon and build bridges between the Mediterranean Sea and oil fields in Iraq. ${ }^{3}$

This discussion is a historical discussion that begins with the systematic collection and evaluation of data relating to past events to test hypotheses relating to cause and effect or political tendencies. These events can help describe or explain the current events experienced by Muslims in the Middle East and Palestine in particular and anticipate future events.

\section{WESTERNIZATION OF POLITICS AND JEWISH EXODUS}

Initially, charitable social foundations were formed for the process of westernization, which had not yet been read by the Ottoman Empire at that time. The purchase of housing complexes and other properties

3 Muhammad 'Īsā Șālihīya, Madīnat al-Quds: as-sukkān wa-'l-arḍ ; (al- 'Arab wa-'l-Yahüd) ; 1858 - 1948m ; 1275 - 1368h, Ṭab'a 1 (Bairūt, 2009), 159. 
was facilitated and protected by a legal umbrella in 1858 . There was a massive Jewish move to Palestine by buying land from landlords in the Ottoman region far from his land. That way, the landowners were not aware of what is happening to the lands they have sold. Jews dared to buy these lands at very high prices, and the Western Consuls protect them in the area. They were not in the realm of Ottoman Law due to the long-signed agreement by the Empire following the 1867 agreement that allowed foreigners to have immovable assets in Ottoman territory.

\section{a. Muhammad Ali Pasya's Demeanour towards Jews}

At first, Muhammad Ali Pasha was very interested in the offer of a British-Jewish royal nobleman, Sir Moses Haim Montefiore, but the proposal that had no consequences that Favoured Muhammad Ali. ${ }^{4}$ Sir Moses Haim Montefiore was allowed to contract land in Palestine for 50 years that was exempt from taxation, and the Jews had the right to invest in the land and brought agricultural experts to train Palestinians in farming. The failure of Egypt's expansion into Sham made the project fail. However, there is another version that Pasha rejected the project because, at that time, the country of Sham was unstable in $1838 \mathrm{AD}$. Egypt withdrew from Sham and failed to plan the great state of Muhammad Ali Pasha, who would integrate Egypt, Sham, and Iraq. ${ }^{5}$ However, undeniably Muhammad Ali Pasha tried hard to gain Western sympathy by providing facilities for missionary groups and consul delegates and opening the door for minority groups and providing protection to them. This was done to create an image that Muhammad Ali Pasha was a person worthy of establishing a modern state. It is as if the West needs a modern country that will stand in the Middle East. ${ }^{6}$

\section{b. Supporters of Reform and Dependence on the West}

The reformers carried out the Western and Zionist plans of dividing Muslims. He is Midhat Pasha, the father of Turkish-backed Turkish

4 Yoseph Hagar Yosep Hagar and Peturs Hallaq, Al-Uruba Wa Mashir asSyarq al-Arabi: Harb al-Isti'mar Ala Muhammad Ali Ala Nahdhah al-Arabia (Beirut, Lebanon: Muasasah ar-Risalah, 1976), 233.

5 Nailah Wa'ri Nailah Wa'ri, Daur Konsuliyat al-Ajnabiyah fi al-Hijrah wa istitan al-Yahudi fi Filisthin 1840-1914 (Beirut, Lebanon: Dar as-Shafa, 2007), 63.

6 Ibid., 104. 
law and constitution in Syria, which later became prime minister and Khairuddin at-Tunisi, who also served as prime minister of the Ottoman state, other officials. ${ }^{7}$ They were deceived by the offer of a lot of money from Laurence Oliphant, and not only there they also received political support in the early days of Sultan Abdul Hamid II. ${ }^{8}$ The head of the Arab Unity Conference also approved the transfer of Jews from various regions to settle in Palestine. One of them was Shaykh Abdul Hamid Zahrawi and his group, who were present at the conference. ${ }^{9}$ Also present at the meeting were representatives of the Jews. Zahrawi asserted, "Jewish migration to Palestine was not only a matter of desire but also a necessity. ${ }^{10}$

\section{MASSACRE OF JEWS IN RUSSIA AND EUROPEAN ATTITUDES}

The assassination of the Russian Tsar Alexander II in 1881 AD made Jews depart from Russia. So the desire arose to find a new settlement for these Jews, namely in Palestine. The beginning of Russian Jewish migration to Palestine in 1882, to address this the Ottoman law, was issued, which allowed Jews to migrate to the Ottoman territories except for Palestine, and they must obey all laws in the Ottoman territory. This was set in April 1882, and this ban was confirmed in June 1882 through the telegram of Sultan Abdul Hamid II, which was submitted to the Quds, Haifa, Beirut, and Laziqiyah regional governments not to accept Jews who moved from Russia, Romania, Bulgaria to the Palestinian territories. ${ }^{11}$ The Jewish emigration was started from Eastern Europe. Still, the Ottoman Empire was aware of the danger of Jews gathering in this Palestinian territory, and the Ottoman government banned Jews from all over the world to settle

7 Lawrence Olphant Oliphant, Ardhul Jal'ad Rihlaat fi Lubnan wa Suriah wa al-urdun wa Filistin 1880 (Beirut, Amman: , Dar al-Majdlawi li an-Nasr wa Tawzi, 2004), 430.

8 Alizar Meirison, "Islamic Sharia and Non-Muslim Citizens in Kanunname During Sultan Abdul Hamid II of the Ottoman Empire," UIN Walisongo Vol 27, no. No 1 (2019) (2019): 37-68, doi:http://dx.doi.org/10.21580/ws.27.1.3543.

9 Abdul Aziz Muhammad Iwadh, Muqadimah Fi Tarikh Filisthin Al-Hadits, 1831-1914 (Beirut, Lebanon: Muasasah al-Arabiyah lidiraasat wa an-Nasyr, 1983), 153.

${ }^{10}$ Ibid., 154.

${ }^{11}$ Husain Shabri Husain Shabri, Siyasah Al-Isti'mar Wa Shahiyuniyah Tijah Filisthin Fi Nisfi al-Awal Min al-Qarnil Isyriin (Kairo: Dar al-Ma'arif, 1973), 12. 
there and began to put up a post in areas leading to Palestine, such as Syria and Beirut. The regulations issued were specifically applied to Jews who emigrated from Russia because they could bring a lot of problems, while those who migrated from other places were not so conspicuous due to their small numbers. This problem had triggered the Muslims in Palestine to show their original character, which so far has been quite tolerant of the religions around the Palestinian territories.

\section{The Volume of Jewish Migration to Palestine during the Ottoman Empire}

The Ottoman ban on Jewish migration was ineffective because Western countries fully supported the Jewish emigration. The Ottoman Empire had long been bound by the Capitulation agreement signed by Ottoman rulers from generation to generation, starting from Bayazid I's era. This capitulation agreement initially brought about economic benefits, but soon after it backfired and made the Ottoman Empire a Western and Russian cash cow. The second cause is rasuah (bribery), which is carried out by Zionist because they are experts in corruption. Jews have changed their citizenship from Russia to British and France citizenship. Western countries assisted the process by helping to bribe the Ottoman administration to allow these Jewish immigrants to enter Palestinian territory because they held foreign citizenship and were no longer Russian citizens. ${ }^{12}$ There were different figures in the number of Jews who had emigrated to Palestine at that time. The Ottoman statistical office did not recognize the actual number of Jews except those who had been permitted for live or who had long settled in Palestine. While the Zionists maximize the amount of the Jewish population in Palestine, even those who had died were considered still alive and were replaced by new Jews who emigrated. Jewish propaganda spread everywhere by describing the inflated numbers of Jews who had emigrated to the land promised to them. The propaganda of the Jewish emigration, their suffering, the achievements produced in Palestinian land has encouraged donors to spend their wealth to help the Jewish migrants. At the same time, the statistics of foreign consulates were also inaccurate because they tried to hide the real numbers to prevent the increasing vigilance of

\footnotetext{
${ }^{12}$ Muhammad Iwadh, Muqadimah Fi Tarikh Filisthin Al-Hadits, 1831-1914, 31.
} 
the Ottoman government in preventing the Jews from moving to Palestine.

Western sources describe the number of Jews who emigrated to the Land of Palestine before the migration of Russian Jews to around 25,000 people. They had moved to Palestine before The First World War erupted in 1914, reaching 85,000. Their number had reached 11$12 \%$ of the total Palestinian population at that time. The people of Palestine at that time had reached 700,000. According to consistent population growth, the number of Jews should only reach 50,000, according to Walid Khalidi. ${ }^{13}$ Most of the Jews who emigrated lived in cities such as al-Quds, Yafa, Shafad, al-Khalil, Haifa, and ten other occupied territories. They succeeded in establishing social and economic institutions and have tried to establish a university but failed. They also tried to determine their existence politically, but it did not last long. ${ }^{14}$ The number of Jews recognized by the Ottoman Government in Palestine is only 6\% of the population count carried out by the West. Because of that, Britain, France, and the United States continued to pressure the Ottoman Turks politically and economically for the smooth exodus of Jews to Palestine.

\section{The Ottoman Administrative Process and Continuous Jewish Migration}

In 1877-1898 Rauf Pasha acting as Mayor of al-Quds tried hard to block the Jewish migration to the city and not to issue new building permits so that Jews built houses illegally. In 1884 a regulation was issued restricting Jewish pilgrimage to Palestine to no more than 30 days. After protests by Western countries over the treatment of the Ottoman government against Jews in 1887, the length of the Jewish pilgrimage was extended for three months. This regulation was applied to Jews who had emigrated and had just arrived. From this regulation, it has seen the seriousness of the Ottoman Empire in blocking the flow of Jews towards Palestine. The law was also socialized to the heads of regions in Sham and Palestine, which also included the Sham region to expel Jews if they remained in residence

${ }^{13}$ Walid Khalidi Walid Khalidi, Filistin Wa Sira'atuha Ma'a Shahiyuniyah Wa Israil (Beirut, Lebanon: Muasasah Dirasah Filistiniyah, 2009), 290.

${ }^{14}$ Abdul Aziz Muhammad Syanawi, Daulah Usmaniyah Daulah Islamiyah Muftara Alaiha, vol. 2 (Kairo: Dar an-Nahdhah Misriyah, 1988), 991-98. 
after making a pilgrimage to Palestine. Even the Ottoman government sent a detailed standard procedure in preventing the Jewish migration to Palestine. ${ }^{15}$

In 1888 the Turkish government forced Jews who came in with passports explaining their creed and who did not obtain visas from the Turkish government could not enter Palestine. ${ }^{16}$ The pressure continued to arrive from Europe, and these regulations only applied to Jews who came from England and which could be prevented only came with groups, not individuals. ${ }^{17}$ In 1891 there was an exodus of Jews who were also supported by the United States and Britain. A Jewish exodus has taken place, resulting in protests from the Palestinian population. ${ }^{18}$ After that, a new regulation was issued which forbade Jews who either had Ottoman citizenship or not. They could not have amiriyah land (agricultural land controlled by the government). Sultan Abdul Hamid II issued a regulation that forbade Jews to stay in Palestine and formed a government there, the Sultan wrote the rule many times and wrote it in his own hand. In 1896 the Ottoman Empire allowed Jews who had settled before 1893 to own real estate and forbid Jewish foreign companies to buy a house or real estate. ${ }^{19}$ In 1897 Sultan Abdul Hamid II began to appoint secretaries who were close to him and advisers in the Jewish migration to Palestine. Some of them succeeded in carrying out their duties in stopping the flow of Jews who migrated to the Land of Palestine. ${ }^{20}$ In 1898 the details of the prohibition of the Jewish exodus were sufficiently detailed; the ban included all Jews regardless of nationality to enter Palestine without a security deposit and could show a letter of agreement to stay in Palestine for only one month.

In 1898-1899 Theodore Herzl made the United States ambassador in Istanbul an intermediary to obtain the privilege of allowing missionaries to move freely and not discriminate between Jews and

${ }^{15}$ Muhammad Iwadh, Muqadimah Fi Tarikh Filisthin Al-Hadits, 1831-1914, 50.

16 Ibid., 51.

${ }^{17}$ Stanford J. Shaw and Ezel Kural Shaw, History of the Ottoman Empire and Modern Turkey. Vol. 1: Empire of the Gazis: The Rise and Decline of the Ottoman Empire ; 1280 - 1808, Reprinted (Cambridge: Cambridge Univ. Press, 1995), 13.

${ }^{18}$ Eve Spangler, Understanding Israel/Palestine (Rotterdam: SensePublishers, 2015), doi:10.1007/978-94-6300-088-8.

${ }^{19}$ Muhammad Iwadh, Muqadimah Fi Tarikh Filisthin Al-Hadits, 1831-1914, 88-89.

${ }^{20}$ Ibid., 90. 
Christians from America. He also asked to allow Jews to travel to Syria and Palestine. This request was also made by the United States State Department in Washington so that Jewish missionaries could enter Syria and Palestine. The Sultan told the United States Secretary of State that this was not allowed. ${ }^{21}$ This was conveyed through the Ottoman foreign minister, the ambassador in full command of the United States, asking that the Sultan dismiss his ministers, but the Sultan refused. The privilege (Capitulation) of the United States that he had been enjoying had been lost, which brought relations between the two countries full of tension. ${ }^{22}$

\section{a. The Imperial Resolution of the Jewish Problem by Theodor Herzl}

An imperial settlement was an attempt to place Jews who were constrained by the policies of the Ottoman Empire and the Palestinian people. This migration was assisted by Imperial countries such as England and France. Without the assistance of these Imperial states, the project of the Jewish movement to Palestinian land would never have been successful. Theodor Herzl had learned from the failed policy of establishing an agricultural colony in Palestine in 1882-1897. Even though Jewish bankers and business people have mobilized their funds, this business failed. Therefore Theodor Herzl refused to proceed with the project without recognition before there is an official guarantee and obtains permission to establish a settlement legally. Approximately 100,000 Jewish migrants could not continue the Zionist project because it lacked structure and infrastructure. They were restrained by the Ottoman Government and the Palestinian people in ownership of land, agricultural land, and social institutions and support administrations. Eventually, only 60,000 Jews remained, which included Jews who had long settled in Palestine of Ottoman nationality. After the war, around 30,000 Jews have disappeared; they prefer to settle in Salonika. The number of Jews in Palestine reaches a third of the population, which was

${ }^{21}$ Desmadi Saharuddin et al., "Capitulation and Siyasah Syar'iyah Al-Maliyah Impact on Economic Stability of the 18th \& 19th Ottoman Turks," QIJIS (Qudus International Journal of Islamic Studies) 7, no. 2 (January 6, 2020): 329, doi:10.21043/ qijis.v7i2.4847.

${ }^{22}$ Hasan Hallaq Hasan Hallaq, Mawqif ad-Daulah Usmaniyah min Harakah asShahiyuniyah 1897-1909 (Beirut, Lebanon: Dar an-Nahdhah, 2009), 151-52. 
only about ten percent of the total population. However, after being assisted by Britain in full, the number doubled. ${ }^{23}$ In a short time, the number of Jews had reached 650,000 after the catastrophe in 1948, and the upheaval of Palestinian society resulted from the Imperial settlement. Theodor Herzl had succeeded in realizing his plans after the other Jewish leaders had failed many times. ${ }^{24}$

\section{b. Herzl and Germany: Zionists are once again the benefit of the Ottoman}

After Herzl got the idea to solve this Jewish emigration problem, he immediately traveled to major countries like Germany. He explained his plans to the German Emperor. He asked the German Emperor to discuss this issue with the Ottoman Empire. The first meeting was held in Istanbul when the Emperor visited there. He informed the Sultan that the Jewish population was loyal to the Sultan, and he should be granted autonomy within the Ottoman Empire. The Jewish community will bring success to the Ottoman Empire following the promise given by the Emperor. The Zionists reported there would be an Arab revolution in opposing the Sultan, but the Zionists would be on the Sultan's side and be willing to crush the rebellion. Herzl tried to convince the Sultan that the Zionists would provide benefits to the Ottoman Empire. The Zionists desperately needed a promise from the Sultan as was done in the Belfour agreement so that the Jews could raise funds to overcome the Ottoman debt and develop infrastructure that was needed for the welfare of the people. If the Sultan is able to grant final residence permits in Palestine, Herzl will be able to collect huge amounts of funds to settle the Ottoman debt problem in a short time. ${ }^{25}$ Although Sultan Abdul Hamid II was under the pressure of debt and security issues and political turmoil created by the opposition, he agreed to lengthy negotiations with the Emperor in 1897-1903; a series of these negotiations failed because the Sultan remained in his stance, which prevented the Jewish migration to Palestine. ${ }^{26}$ The offer of financial assistance to be provided by the

${ }^{23}$ Theodor Herzl, The Diaries of Theodor Herzl (Gloucester, Mass.: Peter Smith, 1978), 51.

${ }^{24}$ Abdul Wahab Masiri Abdul Wahab Masiri, Muqadimah Li Dirasah As-Shira' al-Arabi al-Israili (Dimascus: Dar al-Fikr, 2002), 102.

${ }_{25}$ Theodor Herzl, The Jewish State (London: Penguin Books, 2010), 98.

${ }^{26}$ Muhammad Iwadh, Muqadimah Fi Tarikh Filisthin Al-Hadits, 1831-1914, 58. 
Zionists to the Ottoman government did not make much difference to the ban on Jewish migration to Palestine.

Sultan Abdul Hamid II did not care about the offer of money from the Zionists even though it could solve the Ottoman debt problems. The Sult an did not try to keep his image in the eyes of the West despite being in a precarious and debt-ridden situation, unlike most Muslim rulers today. Although the sultan spent much of his youth studying Western culture, he was aware that the problem presented to him was not a cultural problem of society but was related to exploitation and colonialism. ${ }^{27}$ Sultan Abdul Hamid had a distant vision in the Jewish migration to Palestine. Jewish emigration was part of imperialism, which divided Muslims, which ended in chaos and destruction in the Middle East and other parts of the world occupied by Muslims. That is the trap of Western countries who want to enjoy the natural wealth of Muslims, which is full of abundant natural resources. So the Sultan tried to unite Muslims in various ways starting from infrastructure development such as the railroad tracks between Istanbul and Hijaz, spreading pan Islamism through scholars such as Muhammad Abduh, Jamaluddin al-Afghani, Shaik Mustafa Sabri and other scholars. Italian king told him, the Sultan did not want to listen to the lafaz (Word) of independence, but he still allowed the Jews to migrate. The move to Palestine was forbidden because there would be separation, independence, and the establishment of a Jewish state. Herzl also asked the British to be able to set foot in Sinai. But the British government refused because the Jewish occupation of Sinai was not in line with the benefit of the United Kingdom. The Jewish prohibition to concentrate on Sinai has existed since the time of Sultan Salim I (1517). The Ottoman Empire was a stronghold of Muslims who were torn down by irresponsible hands consisting of Muslims loyal to the West. The Jewish occupation of Sinai began during the British occupation, which allowed the Zionists to survey the conditions and situation in Sinai in 1902.

${ }^{27}$ Fahriye Begum Yildizeli, "Sultan II.Abdulhamid ve William E. Gladstone Uzerine Karsilastirmali Bir Analiz," Journal Of History School 11, no. XXXVII (January 1, 2018): 316-36, doi:10.14225/Joh1436. 


\section{The Demeanor of Ittihad ve Terakki Cemiyeti as Opposition Party}

The Sultan, in his diary, said to his Shaykh, Mahmud Shamat, about a letter sent by British businessman John Boulough in November 1908 to the Ottoman government before the Sultan was overthrown. He was willing to be an intermediary between the Zionist Jewish group and the sultan to ask for approval of the placement of Jews in Palestine with Ottoman compensation to be able to take advantage of Jewish influence in the monetary field that was recognized by the world. The Jews breathed relief after Sultan Abdul Hamid II was overthrown and exiled to Salonika. The sultan lived in the home of the Jewish businessman Emanuel Carasso. Emanuel was present when Sultan Abdul Hamid II was kidnapped and imprisoned in the Jewish House of Ittihad ve Terakki Cemiyeti. ${ }^{28}$ The Jewish Magazine has launched a coup against Sultan Abdul Hamid II, who has abused Israel. ${ }^{29}$ The Ottoman Empire's attitude towards Jewish migration to Palestine immediately changed after Sultan Abdul Hamid was couped. Jews took the opportunity by obtaining residence permits and building various kinds of social, administrative, and educational institutions in Palestine. Not only that, but the Jews also managed to control vast agricultural lands. The Ittihad ve Terakki Cemiyeti party showed more sympathy for Jews who had migrated to Palestine. This party does not deny that it stood behind the Jewish migration to Palestine and established a state there. ${ }^{30}$ This was done to meet the empty state treasury and party interests, the change of cabinet continued, but the policy remained unchanged, neither the Ittihad nor the Iilafaf parties. ${ }^{31}$ Arab opposition accused the Ottoman government of not siding with Arabs who no longer carry out the law made by Sultan Abdul Hamid II, and the Arab opposition demands that the ban on Jewish migration to Palestine is re-enacted. ${ }^{32}$ The

${ }^{28}$ Hana Bathatu Hana Bathatu, Tabaqat al-Ijtima'iyah wa al-Harakat atTsauriyah min Ahdi al-Utsmani hatta Qiyam al-Jumhuriyah (Beirut, Lebanon: Muasasah ar-Risalah, 1990), 323.

${ }^{29}$ Hasan Hallaq, Mawqif ad-Daulah Usmaniyah min Harakah as-Shahiyuniyah 1897-1909, 219.

${ }^{30}$ Laila Sabagh Laila, Palestine Under Ottoman Periode, vol. 1 (Beirut: American University Press, 1977), 252.

${ }^{31}$ Muhammad Iwadh, Muqadimah Fi Tarikh Filisthin Al-Hadits, 1831-1914, 351.

${ }^{32}$ Ibid., 344. 
Ittihad ve Terakki Cemiyeti group needed Jewish support in World War I in 1914, which actually hurt the Ottoman Empire. However, the situation changed after the Jews sided with the allies. This made the Ottoman Empire's attitude towards Jews turn around, but the change in attitude was too late.

Although the Ottoman Empire expelled the Jews in Palestine after the war stopped, which ended with the defeat of the Ottoman Empire and Germans, the Jews returned to occupy Palestinian land. End of World War I The Ottoman Empire surrendered the Palestinian territories, Syria, and Iraq to Britain, which was a consequence of the defeat of the war. However, before the war ended, the Ottoman statesman Tal'at Pasha, who was then the prime minister who carried out the massacre of Armenia, agreed with the Jews. This agreement came about through the intermediary Qarasho, who was mediated by the German government to give Palestinians to the Jews under British pressure. $^{33}$

Sultan Abdul Hamid II was once offered money to overcome the country's severe balance of payments deficit and many more excess funds to be given to the Sultan. Theodore Herzl acknowledged this; he would give as much as 150 million British Pounds in the form of gold coins. This amount is following the amount of Ottoman debt to various countries in Western Europe. A number capable of recovering the economy, social and military of a vast country like the Ottoman Empire. However, the Sultan still refused to sell the Palestinian territories to the Zionists. ${ }^{34}$

33 'Abd-al-Wahhāb Muhammad al-Masīin̄, Mausū'at al-yahūd wa-'l-yahūdīya

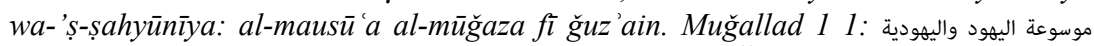
....], Ṭab’a 6 (al-Qāhira: Dār aš-Šurūq, 2010), 221.

${ }^{34}$ Meirison Meirison, "Legal Drafting in the Ottoman Period," Jurnal Ilmiah Al-Syir'ah 17, no. 1 (June 30, 2019): 39, doi:10.30984/jis.v17i1.806.thus opening the opportunity for the authorities to issue legal decisions after being investigated by scholars. The design process is complicated because the books of fiqh do not instantly explain the laws required. The legal drafting process in principle based on the Qur'an and al-Hadith which are manifested by the mufti or Syaik al-Islam after being proposed by the sultan through the prime minister. After obtaining syaikh al-Islam's approval, the law or law is deemed legitimate. With a qualitative approach, the author conducted a literature study and analyzed the data collected and interpreted legal drafting during the Ottoman period. The decline of the Ottoman Empire in various fields has led to renewal including reforms in the areas of legislation, law, and justice which demanded legal codification in the form of majallah Al-Ahkam Al-Adliyah. This Majallah contains the law mu'amalah, which leads to ahwal As-syakhsiyah and serves to maintain Islamic 


\section{c. The Distinction of the Period of Sultan Abdul Hamid II}

Sultan Abdul Hamid II tended to the benefit of Muslims and Arabs who allowed Muslims of various ethnicities to play a role in Ottoman rule. It is different from the policies of the opposition when it gained control of the government of Ittihad ve Terakki Cemiyeti, who was hostile to Arabs. This group did play a policy of tugging with the Zionists after getting pressure from Arab society, which was motivated by political benefit. While the attitude of Sultan Abdul Hamid II against the Zionists was driven by the values of the interest of Muslims based on Islamic Sharia. The Sultan carried out political maneuvers under pressure from Western countries but still did not affect his original direction and objectives. The problem with the placement of Jews in Palestine is not the placement of residents who seek refuge because they have no place to live and suffer torture and massacres. But the problem is instilling the human element that wants to establish a state amid an alien item from humans who will establish the country. The Jews came from various parts of the world who have a variety of cultures and languages. The state was founded as a country with a pattern of Western Imperialism that seized land belonging to the Arabs. Despite pressure from the West, coupled with the corrupt Ottoman government at that time, Sultan Abdul Hamid II continued not to provide a Palestinian land to the Jews. Although Jews are willing to pay all the debts of the Ottoman and improve the economy and financial administration of the Empire, the sultan's decision remained unchanged. Sultan Abdul Hamid II wrote the law banning Jewish migration to Palestine in his own handwriting from firing Palestinian administrators who were bribed by Zionists and foreign consulates. Theodore Herzl did not get his wish from Sultan Abdul Hamid, who was firm in his stand. ${ }^{35}$ Sultan Abdul Hamid had run the Islamic Shari'ah of Islam against the backdrop of his education and his people until he rejected the desirable Jewish offer. An impossible compensation is the release of Palestine from

law, which almost eliminated due to secularity that occurred.","container-title":"Jurnal Ilmiah Al-Syir'ah","DOI":"10.30984/jis.v17i1.806","ISSN":"2528-0368, 1693-4202","issue":"1","journalAbbreviation":"JIS","page":"39","source":"DOI.org (Crossref

${ }^{35}$ Uyar, Mesut; Erickson, Edward. Mesut Uyar and Edward J. Erickson, A Military History of the Ottomans: From Osman to Atatürk (Santa Barbara, Calif: Praeger Security International/ABC-CLIO, 2009), 160.. (Oxford, ABC Clio, 2017),p.160 
the Ottoman territories, which had been painstakingly controlled by the Caliph Umar bin Khattab and then the sultan easily relinquished the land to the Jews. In 1947 war broke out as a result of the transfer of Palestinian sovereignty from the Ottoman Empire, which was formally declared in 1924 to Britain, which led to the catastrophe of 1948 and 1967. The British developed Israeli structural and infrastructure development projects, which were then continued by the United States. ${ }^{36}$

The Jewish migration from 1882 until the beginning of World War I (1914) reached 4 million. ${ }^{37}$ That is much smaller than the movement of immigrants to America, Canada, and Argentina. However, after the collapse of the Ottoman Empire, a large scale occurred every time. Rural communities in Palestine have not felt a direct influence on the Jewish migration there until 1914-1918 after the outbreak of World War I. Previously, and Jews were portrayed as carriers of progress for the Palestinian people who developed agricultural technology. However, the British administration in Palestine had been involved as an intermediary for the sale of land for Zionist interests, which caused farmers to lose land and become guests in their own villages. This is done in various ways, sometimes by forced planting where the low price of harvests and less demand make farmers lose their passion for farming. The high cost of cultivating land coupled with the elevated necessities of life also results in farmers easily selling their estate. Even so, the religious sense of Ottoman officials rose to not play with this Jewish emigration. Bribery and corruption has pervasive everywhere, but for the sale of land in Palestine, not many officials dared to conspire with Jews and consuls of Western Europe and the United States.

One of the Arab leaders who were still under Ottoman territory was Khidewi Abbas, who always tried to approach the Zionist group. ${ }^{38}$

${ }^{36}$ Walid Khalidi, Filistin Wa Sira'atuha Ma'a Shahiyuniyah Wa Israil, 296.

37 Abdul Wahab Masiri, Muqadimah Li Dirasah As-Shira' al-Arabi al-Israili, 91-95.

38 Abbas II Helmy Bey (also known as’ Abbas Hilmī Pasha, Arabic: عباس حلمي باشا) 14) July 1874 - 19 December 1944) was the last Khedive (Ottoman viceroy) of Egypt and Sudan, who ruled from 8 January 1892 to 19 December 1914. In 1914, after the Ottoman Empire joined the Central Powers in World War I, the nationalist Khedive was removed by the British, then ruled Egypt, for the sake of his more pro-British uncle, Hussein Kamel, marking the end of Egypt's four century era de jure as the Empire province Ottoman, which began in 1517. 
He was fired by the British in 1914 for his part in opposing British occupation in Egypt. Because he supported the Jewish occupation of Palestine, the Zionist group tried to improve relations with Britain in 1930. The British compensated for the loss of office and replaced it with a monthly salary of 30,000 pounds. Khidewi invited the Palestinian population to make peace with the Jews to move to the Eastern region of Jordan and leave Palestine for the Zionists. He assured that the Palestinian population that they would not be able to resist the Zionist forces supported by the countries of Western Europe and the United States. Khidewi Abbas tried to persuade Palestinian leaders Amir Shakib to invite Palestinians to emigrate to Jordan, and the Khidewi pressed Amir Syakib with a salary cut, but Amir Syakib; answered "how can a Muslim leader expel Muslims out of Palestine? Do you make yourself a leader and preserve your position in this way? Amir Shakib severed his relationship with the British administration and chose to lose a salary of 30,000 pounds instead of selling the fate of the Arabs and Muslims. ${ }^{39}$

\section{PALESTINIAN COMMUNITY REACTION}

Palestinians feel the loss of protection after the Ottoman Empire collapsed, which always tried to hinder the migration of Jews to their country. They compared the social, economic, and political conditions that existed during the Ottoman Empire and the Post Ottoman Empire, which were very much different. The Belfour Agreement provides fresh air, namely the formation of a Palestinian government in the Western pattern. The consequence of democracy is about transfering the Palestinian people's property rights to the Jews who were already in the minority become the majority. Agricultural land was no longer bought by Jews but was forcibly taken. The banks provided for the Palestinian community in Istanbul that functioned as the development of agricultural lands were taken over by the Jews in 1921. This was done by Herbert Samuel, who had been agreed by the British government to castrate the Palestinian farming business. Arab and Palestinian people were forced to borrow from Jewish banks with very high interest. ${ }^{40}$ Sultan Abdul Hamid II

\footnotetext{
${ }^{39}$ Walid Khalidi, Filistin Wa Sira'atuha Ma'a Shahiyuniyah Wa Israil, 113.

${ }^{40}$ sahar al-Hunaid Sahar al-Hunaidi, Ta'sis al-Brithani lil Watan al-Qaumi al-Yaudi: Fatrah Herbert Samuel (1920-1925) (Beirut: Muasasah ad-Dirasat al-
} 
said, accepting Jews who had been expelled all over the world was an unacceptable case because they would establish a state in Palestine later, whereas the empire's country is not a land without a population that can be occupied by anyone. The Muslim community will suffer from the migration of Jews to Palestine, so these Jews should be returned to their ships and deported back to America and Western Europe. ${ }^{41}$ A country that expels Jews, like Russia, does not reap any criticism. Why do we get criticism and pressure because they do not want to accept the Jews they drive out of their countries? ${ }^{42}$ What was the matter that they were expelled for sure the country that expelled them felt the harm of this Jewish behavior and sentiment. ${ }^{43}$

\section{CONCLUSION}

The West uses the Jewish emigration to realize their benefit in the Muslim-majority Arab world. Westernization is about reform of the government system, such as parliament establishment, legal renewal, technology, and science development. Westernization is one of the reasons made for the Jews movement from all over the world to the land of Palestine. They moved under the pretext of westernizing agricultural land, building structures, and infrastructure supported by a parliament formed as a result of westernization. The

Filistiniyah, 2003), 60 .

${ }^{41}$ Muhammad Farid Bek Al-Muhami, Tarij al-dawla al-'aliyya al-'utmaniyya (Beirut: Dar al-Nafa' is, 2009), 331.

${ }^{42}$ Mim Kemal Öke, "The Ottoman Empire, Zionism, and the Question of Palestine (1880-1908)," International Journal of Middle East Studies 14, no. 3 (August 1982): 329-41, doi:10.1017/S0020743800051965.the growth of anti-Semitism in Germany and Austria as well as the avalanche of pogroms in Russia and East Europe convinced a considerable section of the Jewish intelligentsia that assimilation was no longer a desirable nor a possible solution to the "Jewish Question." They came to realize that Jews were not only a religious group, but also a separate nation, bound by a common faith and sentiment rather than by land. According to these Jewish nationalists, the Jewish Question could only be solved if the Jews stood on a par with other nations, which could be attained by the collective return of Jews to the ranks of the nations as a people living in their homeland. This was why Dr. Theodor Herzl, as the founder of political Zionism, insisted that the Jews should be "granted sovereignty over a portion of the globe large enough to satisfy the rightful requirements of a nation.",",containertitle":"International Journal of Middle East Studies","DOI":"10.1017/S00207438000 51965","ISSN":"0020-7438，1471-6380","issue":"3","journalAbbreviation":”Int. J. Middle East Stud.","language":"en","page":"329-341","source":”DOI.org (Crossref

${ }^{43}$ Fadhil Bayat Fadhil Bayat, Dirasat Fi Tarikh Al-Arab Fi Ahdi al-Utmani (Beirut, Lebanon: Dar al-Madar al-Islami, 2003), 452. 
parliament consists of Jews who have strong economic and political fields. Sultan Abdul Hamid II has a distant view. Although he did not witness the Jewish treatment of Palestinian Muslims and the surrounding area now, he still forbids Jews who came from Western Europe and Russia to settle Palestine. The Arab community in Hijaz and other Arab leaders joined together over British incitement to rebel against the Ottoman Empire. In contrast, the Ottoman is a protector of Palestine from Zionists' migration, especially during the time of Sultan Abdul Hamid II. The result of westernization was the establishment of parliament and opposition parties; the inclusion of Jews in parliament was a huge factor in the collapse of the Ottoman Empire. Not only that, but the Palestinians also lost their freedom and prosperity and can be seen clearly today. The leaders of the Arabian Peninsula who participated in the rebellion had become cash cows. The concentration of Jews in Europe makes European society nervous, but the Jews have strong economic power and monetary influence. It would be more profitable if the Jews lived in Palestine as a political temperature regulator in the Middle East, which is rich in natural resources that can be exploited at any time. This is in line with the Jewish principle that Palestinian land is the land promised to the Jews. Westernization much helped the Jews to play a role in the Ottoman Empire parliament, which was an absolute power held by the Sultan. By using their influence in parliament, the Zionists can kidnap and alienate Sultan Hamid II. They have captured Palestinian land at meager prices. Fertile soil and sea that is rich in oil and gas that cannot be enjoyed by the Palestinian people and even fishers are restricted from carrying out their activities. Westernization is a mere figment that never shows the results.

\section{REFERENCES}

Abdul Wahab Masiri, Abdul Wahab Masiri. Muqadimah Li Dirasah As-Shira' al-Arabi al-Israili. Dimascus: Dar al-Fikr, 2002.

Begum Yildizeli, Fahriye. "Sultan II.Abdulhamid ve William E. Gladstone Uzerine Karsilastirmali Bir Analiz." Journal Of 
History School 11, no. XXXVII (January 1, 2018): 316-36. doi:10.14225/Joh1436.

Fadhil Bayat, Fadhil Bayat. Dirasat Fi Tarikh Al-Arab Fi Ahdi alUtmani. Beirut, Lebanon: Dar al-Madar al-Islami, 2003.

Farid Bek Al-Muhami, Muhammad. Tarij al-dawla al-'aliyya al'utmaniyya. Beirut: Dar al-Nafa' is, 2009.

Hana Bathatu, Hana Bathatu. Tabaqat al-Ijtima 'iyah wa al-Harakat at-Tsauriyah min Ahdi al-Utsmani hatta Qiyam al-Jumhuriyah. Beirut, Lebanon: Muasasah ar-Risalah, 1990.

Hasan Hallaq, Hasan Hallaq. Mawqif ad-Daulah Usmaniyah min Harakah as-Shahiyuniyah 1897-1909. Beirut, Lebanon: Dar an-Nahdhah, 2009.

Herzl, Theodor. The Diaries of Theodor Herzl. Gloucester, Mass.: Peter Smith, 1978.

—. The Jewish State. London: Penguin Books, 2010.

Husain Shabri, Husain Shabri. Siyasah Al-Isti'mar Wa Shahiyuniyah Tijah Filisthin Fi Nisfi al-Awal Min al-Qarnil Isyriin. Kairo: Dar al-Ma' arif, 1973.

Laila, Laila Sabagh. Palestine Under Ottoman Periode. Vol. 1. 1 vols. Beirut: American University Press, 1977.

Masīin, 'Abd-al-Wahhāb Muhammad al-. Mausū 'at al-yahūd wa'l-yahūdīya wa- 'ṣ-șahyūnīya: al-mausū 'a al-mūğaza fi ğuz'ain.

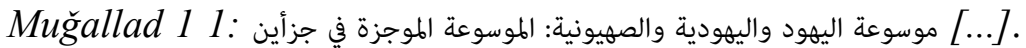
Ṭab'a 6. al-Qāhira: Dār aš-Šurūq, 2010.

Meirison, Alizar. "Islamic Sharia and Non-Muslim Citizens in Kanunname During Sultan Abdul Hamid II of the Ottoman Empire." UIN Walisongo Vol 27, no. No 1 (2019) (2019): 3768. doi:http://dx.doi.org/10.21580/ws.27.1.3543.

Meirison, Meirison. “Legal Drafting in the Ottoman Period.” Jurnal Ilmiah Al-Syir'ah 17, no. 1 (June 30, 2019): 39. doi:10.30984/ jis.v17i1.806. 
Muhammad Iwadh, Abdul Aziz. Muqadimah Fi Tarikh Filisthin Al-Hadits, 1831-1914. Beirut, Lebanon: Muasasah al-Arabiyah lidiraasat wa an-Nasyr, 1983.

Muhammad Syanawi, Abdul Aziz. Daulah Usmaniyah Daulah Islamiyah Muftara Alaiha. Vol. 2. 1 vols. Kairo: Dar anNahdhah Misriyah, 1988.

Nailah Wa'ri, Nailah Wa'ri. Daur Konsuliyat al-Ajnabiyah fi alHijrah wa istitan al-Yahudi fi Filisthin 1840-1914. Beirut, Lebanon: Dar as-Shafa, 2007.

Öke, Mim Kemal. "The Ottoman Empire, Zionism, and the Question of Palestine (1880-1908)." International Journal of Middle East Studies 14, no. 3 (August 1982): 329-41. doi:10.1017/ S0020743800051965.

Oliphant, Lawrence Olphant. Ardhul Jal'ad Rihlaat fi Lubnan wa Suriah wa al-urdun wa Filistin 1880. Beirut, Amman: , Dar alMajdlawi li an-Nasr wa Tawzi, 2004.

Sahar al-Hunaidi, sahar al-Hunaid. Ta'sis al-Brithani lil Watan alQaumi al-Yaudi: Fatrah Herbert Samuel (1920-1925). Beirut: Muasasah ad-Dirasat al-Filistiniyah, 2003.

Saharuddin, Desmadi, Meirison Meirison, Inayatul Chusna, and Ade Sofyan Mulazid. "Capitulation and Siyasah Syar'iyah Al-Maliyah Impact on Economic Stability of the 18th \& 19th Ottoman Turks." QIJIS (Qudus International Journal of Islamic Studies) 7, no. 2 (January 6, 2020): 329. doi:10.21043/ qijis.v7i2.4847.

Ṣālihịiya, Muhammad 'Īsā. Madīnat al-Quds: as-sukkān wa- 'l-arḍ ; (al- 'Arab wa-'l-Yahūd) ; 1858 -1948m ; 1275 - 1368h. Ṭab'a 1. Bairūt, 2009.

Shaw, Stanford J., and Ezel Kural Shaw. History of the Ottoman Empire and Modern Turkey. Vol. 1: Empire of the Gazis: The Rise and Decline of the Ottoman Empire ; 1280 - 1808. Reprinted. Cambridge: Cambridge Univ. Press, 1995.

Spangler, Eve. Understanding Israel/Palestine. Rotterdam: SensePublishers, 2015. doi:10.1007/978-94-6300-088-8. 
Ursinus, Michael. "From Süleyman Pasha to Mehmet Fuat Köprülü: Roman and Byzantine History in Late Ottoman Historiography." Byzantine and Modern Greek Studies 12, no. 1 (January 1988): 305-14. doi:10.1179/byz.1988.12.1.305.

Uyar, Mesut, and Edward J. Erickson. A Military History of the Ottomans: From Osman to Atatürk. Santa Barbara, Calif: Praeger Security International/ABC-CLIO, 2009.

Walid Khalidi, Walid Khalidi. Filistin Wa Sira'atuha Ma'a Shahiyuniyah Wa Israil. Beirut, Lebanon: Muasasah Dirasah Filistiniyah, 2009.

Y1lmaz, Yasir. "Grand Vizieral Authority Revisited: Köprülüs' Legacy and Kara Mustafa Pa'a." Mediterranean Historical Review 31, no. 1 (January 2, 2016): 21-42. doi:10.1080/09518 967.2016.1173359.

Yosep Hagar, Yoseph Hagar, and Peturs Hallaq. Al-Uruba Wa Mashir as-Syarq al-Arabi: Harb al-Isti'mar Ala Muhammad Ali Ala Nahdhah al-Arabia. Beirut, Lebanon: Muasasah arRisalah, 1976. 